\title{
Children with Special Need: Care and Family Support
}

\author{
Fozia sharief, \\ Research Scholar Department of Sociology and social work Dr. C.V Raman University, Bilaspur (C.G)
}

\begin{abstract}
All parents look forward to having a normal and healthy baby. The confirmation of disability in their child shakes the family and serves as a source of severe psychological disruption to family adjustment. Accepting a child with disability becomes difficult for parents and the family, when competence and achievement are important in the competitive world. The first few years of the child's life are crucial. During this period he learns about herVimself and the world around him Ver. For the disabled child, the experience of growing and learning can be painful and frustrating. It becomes more painful, when the disabled child comes from an environment where survival is an everyday struggle. Thus, when it suddenly becomes necessary for family to love someone who has a very limited capacity, the family is put in a conflicting situation, resulting in a great deal of stress. There should be a team approach to parenting, including shared responsibility for decisionmaking and child management. A supportive family environment helps each family member to develop confidence and self-respect.
\end{abstract}

\section{Introduction}

Disability refers to certain limitations which capacitate a person from doing or deprive him or her from the power of acting [1]. The term is conceived differently in the society. Some people believe that it is a curse of God and atonement is sought by resort sacrifices, charity or visit to holy places. Some relate it to their own deficiencies and develop a feeling of guilt which results in isolation of the disabled child by hiding him from others. Some have no idea about what is wrong with the child while others perceive it as a form of mental illness. Children truly are future of our nation. We owe to them and our nation. To ensure that all children are born with the best possible chance to live, love, grow and excel. We do not know why one baby is born disable while next is perfect and healthy. A life which would require greater acceptance, love and care is considered useless and held to be an intolerable burden and is therefore rejected. All children need the warmth of physical affection and disabled children need it perhaps even more than others. Raising a child with disability poses many challenges for the family. The disabled child as well as his family experiences the stress and strain. Disabled persons strive for the independence, need for social approval and have inadequate knowledge to tackle varied problems. The level of parental apprehension is variable in intensity for different parents of handicapped children. Initially the parents are faced to accept his or her powerlessness to prevent the catastrophe that had happened. The future seems bleak with the never ending expenditure of energy and resources to provide care to the child. At each stage of development the family and community has to grapple with this reality. Caring for disabled child is never easy. It needs enormous amount of time, patience and love. In most communities, parents and close family members will be the main care providers. Family needs a lot of support from the community in order to care adequately for the child. Family support model helps the family and community to provide adequate care to disabled children with less stress and strain.

\section{Methodology}

The study was conducted in the rural areas of Anantnag and Kulagam districts of state of Jammu and Kashmir, India. It was decided to contact the parents of the children of the above mentioned districts. A list along with the home addresses of the children were collected from the resource teachers appointed by sarvashiksha Abhiyan and various NGO's dealing with children with special care. The data was collected from a well structured interview schedule to draw a sample of 150 families having children with either of the four disabilities viz. mental retardation, speech and hearing impaired, visually impaired or orthopedically challenged.

\section{Research Instrument:}

A self-structured interview schedule was prepared. It was administered to the families following rapid appraisal of the status of care of these children in the families. The questions were framed keeping in view the following aspects of research: family care system, interpersonal relationships, roles and responsibilities of different family members towards disabled child, physical care of the disabled child, educational and emotional care of the disabled child and sibling relationship. 


\section{Collection of Data:}

For the purpose of data collection, the respondents of the selected samples were interviewed individually. The framed questions were asked to the respondents to collect the required information. Families were classified according to the educational status of the parents i.e. illiterate and literate. Percentages of the scores were computed obtained for various quantitative variables.

\section{Result And Discussion:}

Like all other children, a disabled child is born in a family and remains a lifelong member of that family. Among all social institutions, schools, community, peers and family, the family is universally regarded as exerting the most significant influence on the child's development as it provides love, care, support, protection, guidance and direction to children. The life of a disabled child is intervened with that of his family the parents and the siblings. The way parents and siblings treat a disabled child is a reflection of the attitude they have for disability.

\section{Characteristics and Composition of the Sample:}

A sample of 150 disabled children was selected for study whose ages ranged from birth to twelve (12) years. These children were classified into two groups i.e. 0-6 years and 6-12 years. Father, mother and significant other person in the family of each of the 150 disabled children were the respondents. The families were classified according to the educational status of the parents i.e. illiterate and literate (Table 1).

Table 1: Families as per parent's educational characteristics

\begin{tabular}{|c|c|c|c|c|c|c|c|c|c|c|c|}
\hline \multirow{2}{*}{$\begin{array}{l}\text { Parent's } \\
\text { educational } \\
\text { characteristics }\end{array}$} & \multicolumn{2}{|c|}{ Age group } & \multicolumn{3}{|c|}{ Type of family } & \multicolumn{2}{|c|}{ No. Of siblings } & \multicolumn{4}{|c|}{ Birth Order } \\
\hline & $\begin{array}{l}0-6 \\
\text { years }\end{array}$ & $\begin{array}{l}6-12 \\
\text { Years } \\
\end{array}$ & $\begin{array}{l}\text { Nucle } \\
\text { ar }\end{array}$ & Joint & $\begin{array}{l}\text { Extend } \\
\text { ed }\end{array}$ & $0-2$ & $\begin{array}{l}\text { 3- } \\
\text { above }\end{array}$ & 1 & 2 & 3 & 4 \\
\hline $\begin{array}{l}\text { Father } \\
\text { Illiterate } \\
\text { Mother } \\
(\mathbf{n}=79)\end{array}$ & $\begin{array}{l}25(32 \\
\%)\end{array}$ & $\begin{array}{l}54(68 \\
\%)\end{array}$ & $\begin{array}{l}50(64 \\
\%)\end{array}$ & $\begin{array}{l}25(31 \\
\%)\end{array}$ & $4(5 \%)$ & $\begin{array}{l}45(57 \\
\%)\end{array}$ & $\begin{array}{l}34(43 \\
\%)\end{array}$ & $\begin{array}{l}21(27 \\
\%)\end{array}$ & $\begin{array}{l}38(48 \\
\%)\end{array}$ & $\begin{array}{l}\text { 17(21 } \\
\%)\end{array}$ & $\begin{array}{l}3(4 \\
\%)\end{array}$ \\
\hline $\begin{array}{l}\text { Illiterate } \\
(n=79)\end{array}$ & & & & & & & & & & & \\
\hline 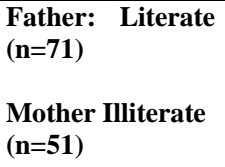 & $\begin{array}{l}21(41 \\
\%)\end{array}$ & $\begin{array}{l}30(59 \\
\%)\end{array}$ & $\begin{array}{l}30(59 \\
\%)\end{array}$ & $\begin{array}{l}10(22 \\
\%)\end{array}$ & $\begin{array}{l}11(19 \\
\%)\end{array}$ & $\begin{array}{l}31(60 \\
\%)\end{array}$ & $\begin{array}{l}20(40 \\
\%)\end{array}$ & $\begin{array}{l}15(29 \\
\%)\end{array}$ & $\begin{array}{l}17(33 \\
\%)\end{array}$ & $\begin{array}{l}11(22 \\
\%)\end{array}$ & $\begin{array}{l}8(16 \\
\%)\end{array}$ \\
\hline $\begin{array}{l}\text { Literate } \\
(n=20)\end{array}$ & $\begin{array}{l}7(35 \\
\%)\end{array}$ & $\begin{array}{l}13(65 \\
\%)\end{array}$ & $\begin{array}{l}10(50 \\
\%)\end{array}$ & $\begin{array}{l}6(30 \\
\%)\end{array}$ & $\begin{array}{l}4(20 \% \\
)\end{array}$ & $\begin{array}{l}14(70 \\
\%)\end{array}$ & $\begin{array}{l}6(30 \\
\%)\end{array}$ & $\begin{array}{l}10(50 \\
\%)\end{array}$ & $\begin{array}{l}5(25 \\
\%)\end{array}$ & $\begin{array}{l}5(25 \\
\%)\end{array}$ & - \\
\hline Total & $\begin{array}{l}28(39 \\
\%)\end{array}$ & $\begin{array}{l}43(61 \\
\%) \\
\end{array}$ & $\begin{array}{l}40(56 \\
\%)\end{array}$ & $\begin{array}{l}16(23 \\
\%)\end{array}$ & $\begin{array}{l}15(21 \\
\%)\end{array}$ & $\begin{array}{l}45(63 \\
\%) \\
\end{array}$ & $\begin{array}{l}26(37 \\
\%)\end{array}$ & $\begin{array}{l}25(35 \\
\%) \\
\end{array}$ & $\begin{array}{l}22(31 \\
\%)\end{array}$ & $\begin{array}{l}16(23 \\
\%)\end{array}$ & $\begin{array}{l}8(11 \\
\%) \\
\end{array}$ \\
\hline
\end{tabular}

\section{Primary Care Givers:}

Providing proper care to the disabled child is a challenge for the family. Accepting the disability of the child is very difficult for the family members especially the parents. The care of the disabled child is affected by the type of family, number of siblings and age of the child[1][2]. The caregiver of the disabled child requires support from the other family members and also from outside the family Results show that majority of the disabled children are primarily taken care by their mothers. Mothers are the primary care-takers not only of the disabled children but provide care and fulfill the needs of their children either s/he is disabled or not [3]. In joint and extended families this task is shared by grandparents. In some families when the disabled child has elder sibling and the sibling is at home, s/he provide the primary care to his/her sibling. Primary care givers to the child vary according to type of family, number of siblings, age of the child etc. In few cases it was observed that father is the primary care giver of disabled child, especially in those families where mothers are either working or demised. Caregivers and child affect each other mutually, in complex ways. A healthy infant is born with an amazing capacity to engage adults and communicate needs but most important to make that adults fall in love with them[3]. But demanding behaviour characteristics of child make difficult to care for, even for the most capable and patient parents. (Table 2). 
Table 2: Primary care givers

\begin{tabular}{|l|l|l|l|}
\hline S. No & Care Givers & Number & Percentage \\
\hline 1 & Mother & 96 & 64.0 \\
\hline 2 & Father & 3 & 2.0 \\
\hline 3 & Siblings & 28 & 19.0 \\
\hline 4 & Grandparents & 23 & 15 \\
\hline & Total & 150 & 100 \\
\hline
\end{tabular}

\section{Physical Care of the Disabled Child:}

The quantity and quality of the care provided by the family to the disabled child is linked by the degree of child's dependence for his/her physical care i.e. feeding, bathing, dressing etc. The results indicate that 75 percent of disabled children were dependent upon others for their physical care (Table3)

Table 3: The disabled child could take care of him/herself

\begin{tabular}{|c|c|c|c|c|}
\hline \multirow{3}{*}{$\begin{array}{l}\text { Parent's } \\
\text { educational } \\
\text { characteristics }\end{array}$} & \multicolumn{4}{|c|}{ The disabled child could take care of him/herself } \\
\hline & \multicolumn{2}{|c|}{ Yes } & \multicolumn{2}{|c|}{ No } \\
\hline & $\mathbf{N}$ & $\%$ & $\mathbf{N}$ & $\%$ \\
\hline $\begin{array}{l}\text { Father: Illiterate } \\
(\mathbf{n}=79) \\
\text { Mother Illiterate } \\
(\mathbf{n}=79)\end{array}$ & 18 & 22 & 61 & 78 \\
\hline \multirow{2}{*}{$\begin{array}{l}\text { Father: Literate } \\
(\mathbf{n}=71) \\
\text { Mother Illiterate } \\
(\mathbf{n}=51) \\
\text { Literate }(\mathbf{n}=\mathbf{2 0})\end{array}$} & 12 & 24 & 39 & 76 \\
\hline & 5 & 25 & 15 & 75 \\
\hline Total & 17 & 24 & 54 & 76 \\
\hline
\end{tabular}

It is difficult for the caregivers to be around him/her all the time and sometimes they ignore the child. The ignoring act could be mild, occasionally but there are instances of it being extreme. However, the cumulative affect of ignoring could not be ruled out as a contributing factor in gradually deteriorating condition of the child[5] .Discomfort because of dependency of the disabled child has been expressed by 85 percent of caregivers (Table 3.1).

Table 3.1: Family faces discomforts due to the disabled child

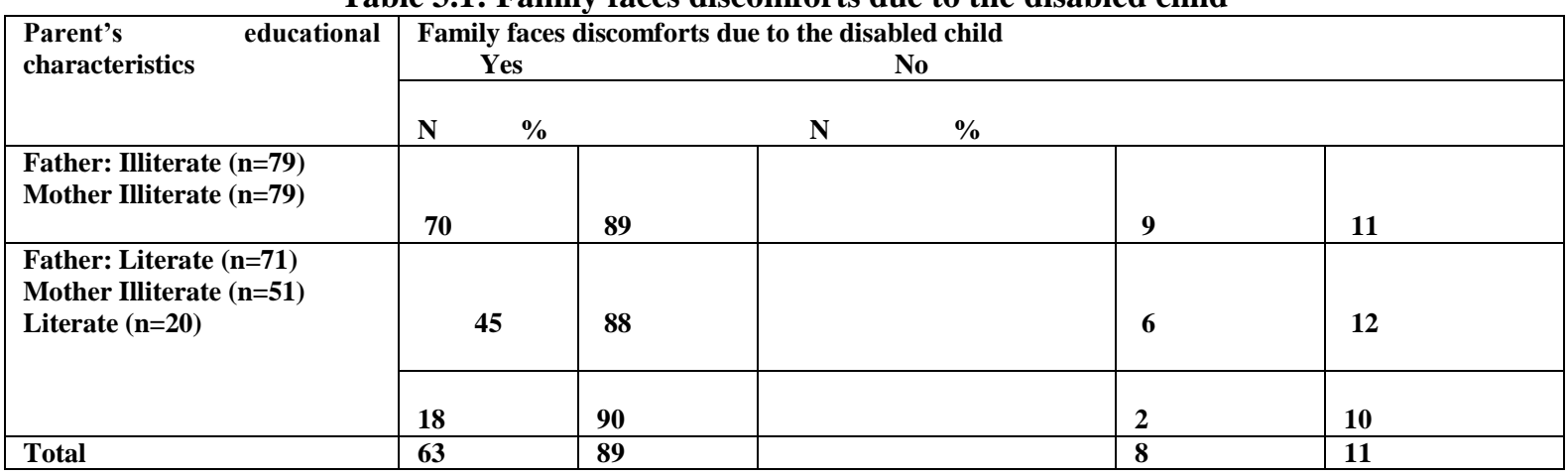

The physical care i.e. bathing, dressing, feeding etc. provided to the disabled child varies from family to family. Some of the factors which were observed in majority of the families which affected the care provided to the disabled were associated with strain of care of the disabled child, additional time involved in care for the child, the possibility of neglecting other family members and difficulty to maintain harmony and resources of the family. Seventy per cent of the families did not provide medical check-ups to their disabled children. Around thirty percent in all three categories provide medical check up to their children (Table3.2). 


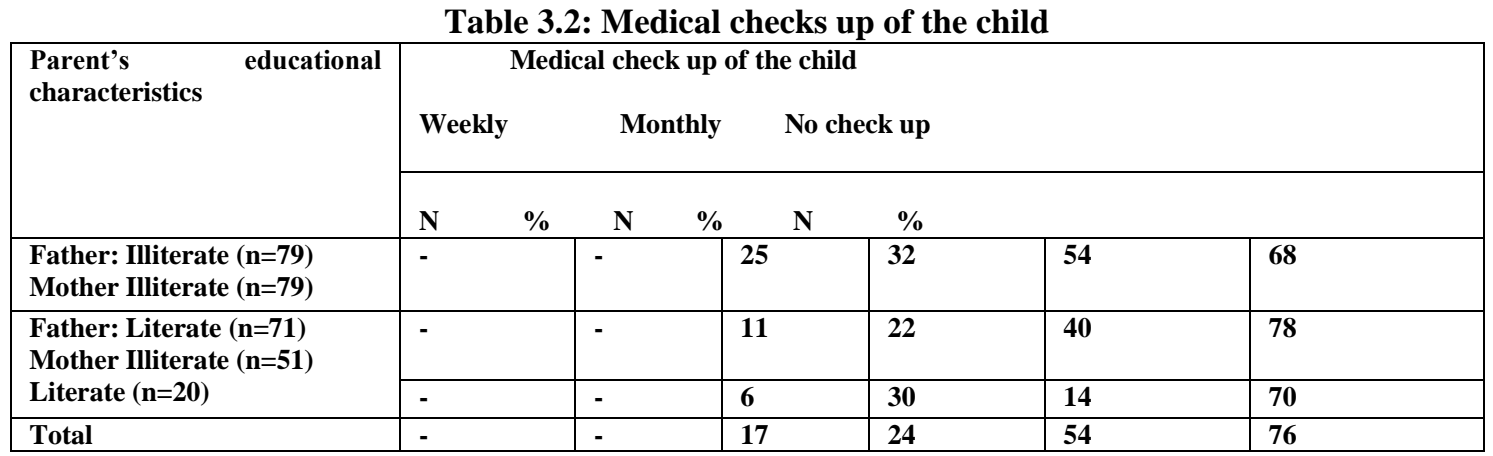

This all depends upon the parent's interest and understanding in their disabled child. Investigator came across such families, which were economically unsound. Despite economic hardships, they were providing better care including regular medical check-up of the disabled child. The families considered it to be their duty to take care of him. The quantity and quality of the care provided to the disabled children vary from family to family according to their values.

\section{Educational Care to the Disabled Children:}

Families perceived the disabled children unable to learn anything. So, they did not put any effort to provide them any special education or to enhance any creative skills in their child(Table 4). This is because of lack of knowledge and lack of awareness regarding existing technologies, which enhance their child's skills. Most of the parents overestimated the abilities of their disabled children. Parents sometimes set goals and expectations so high that they are unattainable and lead to disappointments and negative feelings [4][5]. Child disability must be understood in proper way to provide them the care i.e. educational, physical, and emotional care in proper way, to make them the independent and socially accepted individual.

Table 4: Provision of special education to the disabled child

\begin{tabular}{|c|c|c|c|c|c|c|}
\hline \multirow{3}{*}{$\begin{array}{ll}\begin{array}{l}\text { Parent's } \\
\text { characteristics }\end{array} & \text { educational }\end{array}$} & \multicolumn{6}{|c|}{ Provision of special education to the disabled child } \\
\hline & \multicolumn{2}{|c|}{ Yes } & \multicolumn{2}{|c|}{ No } & & \\
\hline & $\mathbf{N}$ & $\%$ & $\mathbf{N}$ & $\%$ & & \\
\hline $\begin{array}{l}\text { Father: Illiterate }(n=79) \\
\text { Mother Illiterate }(n=79)\end{array}$ & - & - & & & 79 & 100 \\
\hline $\begin{array}{l}\text { Father: Literate }(n=71) \\
\text { Mother Illiterate }(n=51) \\
\text { Literate }(n=20)\end{array}$ & 2 & 4 & & & 49 & 96 \\
\hline & - & - & & & 20 & 100 \\
\hline Total & 2 & 3 & & & 69 & 97 \\
\hline
\end{tabular}

\section{Parenting Style Followed by the Parents:}

Children with disabilities were perceived as less valuable than other children. A child with difficult behavior pattern or communications difficulties becomes a target of hard discipline. Family needs an enormous amount of time, patience and love. Results indicate that 50 per cent of the parents follow indulgent type of parenting style, 30 per cent authoritarian and 20 per cent follow neglecting style (Table 5).

Table 5: Parenting style followed by parents

\begin{tabular}{|c|c|c|c|c|c|c|c|c|}
\hline \multirow{3}{*}{$\begin{array}{l}\text { Parent's } \\
\text { characteristics }\end{array}$} & \multicolumn{6}{|c|}{ Parenting style followed by parents } & & \\
\hline & \multicolumn{2}{|c|}{ Authoritarian } & \multicolumn{2}{|c|}{ indulgent } & \multicolumn{2}{|c|}{ Neglecting } & & \\
\hline & $\mathbf{N}$ & $\%$ & $\mathbf{N}$ & $\%$ & $\mathbf{N}$ & $\%$ & & \\
\hline $\begin{array}{l}\text { Father: Illiterate }(n=79) \\
\text { Mother Illiterate }(n=79)\end{array}$ & 30 & 38 & & 40 & & 51 & 9 & 11 \\
\hline \multirow{2}{*}{$\begin{array}{l}\text { Father: Literate }(n=71) \\
\text { Mother Illiterate }(n=51) \\
\text { Literate }(n=20)\end{array}$} & 16 & 31 & & 25 & & 49 & 10 & 20 \\
\hline & 7 & 35 & & 11 & & 55 & 2 & 10 \\
\hline Total & 23 & 32 & & 36 & & 51 & 12 & 17 \\
\hline
\end{tabular}




\section{Family Support Model}

It is defined as a schematic description of a system, theory or phenomenon that accounts for its known or inferred properties and may be used for further study of its characteristics.

\section{Network of NGOs with Families:}

NGOs play an important role in the development of society. They focus on the empowerment of depressed sections of the society. There are NGOs working for rehabilitation of disable children in so many areas of $\mathrm{J} \& \mathrm{~K}$, especially in Srinagar city for the convenience of both districts, Anantnag and Kulgam. They also organize camps for the disabled child like wheel chairs etc. So, NGOs should build network with families of disabled children and provide them adequate knowledge about care of the disabled member.

\section{More Interactions with Families among Themselves:}

Families should interact with each other to provide appropriate and rehabilitative care to the disabled child at home. They should help themselves through transfer of knowledge and skills and on findings ways to change and adopt according to the needs of the disabled member.

3. Counseling Services for Families with Special Focus on Siblings: The inability of any person, who is significant to the family, interferes in the family's home and social environment. Every member of the family experiences burden of responsibilities and lack of resources to provide adequate care to the disabled. Sibling disability has a negative impact on the normal sibling's personality. They experience isolation, anger, depression, fear and frustration because of their disabled sibling. Counseling services should be provided to families with special focus on siblings to release their anger, frustration, fear and depression.

\section{Education about Balanced Nutrition and Personal Hygiene:}

Families should be educated balanced nutrition, malnutrition, infectious diseases and personal hygiene. Rural families lack resources particularly in health and education sectors. They must be provided with the appropriate knowledge, which would help them to provide a healthy environment to their disabled member.

\section{Education about Disability:}

Majority of the families lack knowledge about disability, its causes and treatments, which is an important reason for anxiety in parents. They should be provided with the adequate knowledge about the disability and ways to understand and to cope up with the disability of the family member.

\section{Frequent Medical Check ups:}

A major health care challenge for rural areas of the developing countries is lack of access to medical facilities, due to which disabled are not being properly medically checked-up. Special care and attention regarding treatments of the disabled should be provided to the families.

\section{Stress Busting Exercises for the Families:}

Stress is very common among families of disabled. They should be provided with knowledge about stress busting exercises like yoga, meditation etc. Exercise is the best way to diminish the effects of stress . Conflicts arise from negative thoughts, actions and feelings. Conflicts can be resolved by focusing on positive thoughts, actions and feelings.

\section{Inter Personal Relationship Management:}

Management of interpersonal relationship is very important to cope up with the disability of the family members. It also helps to ease the family's progress through an extremely stressful situation.

\section{Emphasis on Inclusive Education:}

Education provided to the children with disabilities should be inclusive. A student should not be excluded from school, because he has disability. Some separate educational facilities are available in our society. It is difficult to locate fully inclusive education systems but it can begin at local school level. A welldeveloped inclusive practice, which give equivalent attention to disabled students, are less expensive then segregated one.

\section{Provision and Access of Literature and Audio-Video Information:}

There should be provision and access of literature and audio-video information on various topics related to disability i.e. management of disabled, causes of disability, sanitation, hygiene etc should be introduced to the families to make them aware about "what disability is" "how it is taken care off". 


\section{Conclusion}

Constant psychological stress, negative effect on siblings, misunderstanding within the family and economic burden were significant factors associated with the families of disabled children. Presence of disabled child hinders family's opportunities for social interactions. The degree of disability affected the care provided to disabled child .Results show that parental way of understanding the disabled child affected the parent-child relationship. When the needs of the disabled child were not understood by the parents, the care was affected to large extent and this leads to the irritated behavior of the parents towards their disabled child. Care and management of the disabled child was found to be related to the extent of child's dependency and the extent of child's behavioral problems. Findings revealed that 64 percent of the disabled children were primarily taken care by their mothers. It was found that parent's lack of knowledge, economic problems and lack of resources affected the care of the disabled child. Disabled child needs extra time for his/her care.

\section{References:}

[1]. Baker-Ericzen, M. J., Brookman-Frazee, L., \& Stahmer, A. (2005). Stress Levels and Adaptability in Parents of toddlers with and without autism spectrum disorders. Research \& practice for persons with severe disabilities, 30, 194-204.

[2]. Behari, M, \& Ruchi, K (1995). The Maternal Attitude of Child-Rearing link of Mentally Retarded Chidren: A Study of Some Sociopsychological influences. Disabilities and Impairement. 9, 44-51.

[3]. Beresford, B. and Oldman, C (2002) Housing Matters: National Evidence Relating to Disabled Children and their Housing, Bristol: Policy Press.

[4]. Dharitri R, Murthy V. N. Hearing Impaired Children: Their behavior problems and Parental attitudes. Journal of Clinical Psychology, 1990, 17(1), 12-16.

[5]. Faber, B., and Jenne, W.C. "Family Organization and Parent-Child Communication: Parents and siblings of a Retarded Child". Monograph Soc. Res. Child Developm., 1963,28, whole No. 91.

[6]. Farheen A Sanjay Dixit, S.B.Bansal, Veena Yesikar, Coping Strategies in Families with Mentally Retarded Children, Indian Journal for the practicing Doctor, vol. 5, (2008-11-2008-12)

[7]. Friedrich, W. N., \& Friedrich, W.L. (1981) Psychological Aspects of Handicapped Children. American Journal of Mental Deficiency, 85, 551-56.

[8]. G. Gathwala, S Gupta, Family Burden in Mentally Handicapped Children, Indian Journal of Community Medicine vol XXIX, No 4, October-December, 2004

[9]. Gibson CS, Maclennan AH, Dekker GA, Goldwater PN, Sullivan TR, Munroe DJ, Tsang S, Stewart C, Nelson KB, Candidate genes and cerebral palsy: a population-based study. Pediatrics. 2008; 122(5):1079-85. 